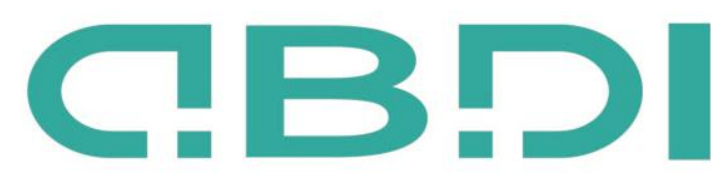

ABDI: JURNAL PENGABDIAN DAN PEMBERDAYAAN MASYARAKAT

\title{
Pemberdayaan Lokal Masyarakat Kelurahan Wonolopo Kecamatan Mijen Kota Semarang Melalui Pengembangan Desa Agrowisata
}

\author{
Sony Junaedii ${ }^{1}$, Endah Dwi Hayati ${ }^{2}$, Muslimah Muslimah ${ }^{3}$ \\ 1,2 Jurusan Bahasa Inggris, Universitas 17 Agustus 1945 Semarang \\ ${ }^{3}$ Jurusan Bahasa Jepang, Universitas 17 Agustus 1945 Semarang
}

E-mail: sojunaedi@gmail.com, endwihayati@gmail.com, muslimaherfan@gmail.com

\begin{abstract}
Abstrak
Kelurahan Wonolopo merupakan desa wisata yang telah ditetapkan menjadi wisata Kota Semarang. Perpaduan antara keindahan alam, kehidupan masyarakat pedesaan dan potensi pertanian, bilamana ditata secara baik dan ditangani secara serius dapat mengembangkan daya tarik wisata bagi kelurahan Wonolopo. Potensi unggulan yang dimiliki oleh kelurahan Wonolopo terutama di bidang pertanian, perkebunan dan pariwisata. Meskipun kelurahan Wonolopo berpotensi untuk menjadi desa agrowisata akan tetapi fakta empirik di lapangan menunjukkan bahwa agrowisata di kelurahan Wonolopo masih belum berkembang. Metode yang digunakan untuk mengatasi permasalahan adalah dengan melakukan pendekatan strategis program yang dilakukan dalam beberapa tahap, yaitu Tahap Persiapan, Tahap Pembinaan dan Pelatihan, Tahap Pendampingan dan evaluasi dalam pembentukan usaha bersama. Secara teknis, rencana kegiatan yang akan diusulkan dalam program ini adalah (1) Workshop perubahan mindset dan menumbuhkan jiwa entrepreneur, (2) Pelatihan dan pendampingan tentang kepariwisataan berbasis MICE dan pengelolaannya, (3) Pembinaan dan pelatihan bahasa daerah dan bahasa asing untuk pemandu wisata (local tour guide), (4) Pelatihan pengolahan produk pertanian, pendampingan, dan pemasarannya, (5) Membuat website, akun facebook, akun instagram, membuat leafet atau brosur paket wisata untuk promosi program desa agrowisata. Dengan adanya kegiatan pengabdian ini diharapkan dapat meningkatkan SDM Kelurahan Wonolopo untuk mengelola potensi alam dan budaya yang dimiliki, meningkatkan kualitas hidup dengan menciptakan kondisi yang lebih baik untuk pertumbuhan ekonomi, penciptaan lapangan kerja sehingga hasilnya benar-benar dapat meningkatkan kesejahteraan masyarakat di sekitarnya.
\end{abstract}

Kata kunci: Desa Agrowisata, Pemberdayan Masyarakat, Potensi Lokal

\section{Abstract}

Wonolopo is a tourist village that has been designated as tourism in the city of Semarang. The combination of natural beauty, rural community life and agricultural potential, if properly managed and taken seriously, can develop a tourist attraction for the Wonolopo village. The superior potential possessed by the Wonolopo village, especially in the fields of agriculture, plantation and tourism. Although Wonolopo has the potential to become an agro-tourism village, empirical facts in the field show that agro-tourism in the Wonolopo village is still underdeveloped. The method used to overcome the problem is to carry out a strategic program approach which is carried out in several stages, namely the Preparation Stage, the Coaching and Training Stage, the Assistance Stage and the evaluation in the formation of a joint venture. Technically, the activity plans that will be proposed in this program are (1) Workshop on changing the mindset and fostering an entrepreneurial spirit, (2) Training and mentoring on MICE-based tourism and its management, (3) Guidance and training for regional and foreign languages for tour guides (local tour guide), (4) Training on agricultural product processing, mentoring, and marketing, (5) Creating a website, Facebook account, Instagram account, making leafets or tour package brochures to promote the agro-tourism village program. With this service activity, it is hoped that the Wonolopo sub-district human resources can manage its natural and cultural potential, improve the quality of life by creating better conditions for economic growth, creating jobs so that the results can actually improve the welfare of the surrounding community.

Key Word: Agro-tourism Village, Community Empowerment, Local Potential

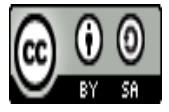

Received: 20 Oktober 2020 Revised: 8 November 2020 Available Online: 9 November 2020

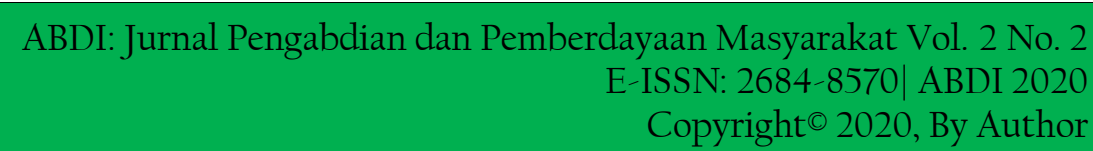




\section{Pendahuluan}

Pengembangan wisata di Kota Semarang mulai dikembangkan desa wisata salah satunya Kelurahan Wonolopo. Berdasarkan Keputusan Walikota Semarang No. 556/407 tanggal 21 Desember tahun 2012 (Pemerintah Kota Semarang, 2012), Kelurahan Wonolopo ditetapkan sebagai salah satu desawisata Kota Semarang. Desa wisata adalah suatu kawasan pedesaan yang menawarkan keseluruhan suasana yang mencerminkan keaslian pedesaan baik dari kehidupan sosial ekonomi, sosial budaya, adat istiadat keseharian, memiliki arsitektur bangunan, dan struktur tata ruang desa yang khas, atau kegiatan perekonomian yang unik dan menarik serta memiliki potensi untuk dikembangkannya berbagai komponen kepariwisataan, seperti atraksi, akomodasi, makanan-minuman dan kebutuhan wisata lainnya (Hadiwijoyo, 2012).

Kelurahan Wonolopo merupakan salah satu kelurahan yang ada di Kecamatan Mijen yang wilayahnya berupa perbukitan. Kelurahan Wonolopo memiliki luas wilayah sebesar $4,04 \mathrm{~km}^{2}$. Adapun batas wilayah untuk kelurahan Wonolopo adalah sebelah utara berbatasan dengan Kelurahan Ngadiro, sebelah selatan berbatasan dengan Kelurahan Jatisari, sebelah barat berbatasan dengan Kelurahan Wonoplumpun dan sebelah timur berbatasan dengan Kelurahan Mijen. Menurut data BPS Kota Semarang tahun 2015, Kelurahan Wonolopo merupakan daerah yang memiliki karakteristik pedesaan dengan karakteristik utama yang didominasi area persawahan dan perkebunan. Kelurahan Wonolopo terdiri dari $10 \mathrm{RW}$ dan 37 RT dan memiliki jumlah penduduk sebesar 7.174 jiwa. Kepadatan penduduk Kelurahan Wonolopo termasuk tertinggi kedua di Kecamatan Mijen setelah Kelurahan Jatisari yaitu sebesar $1.776 \mathrm{jiwa} / \mathrm{km}^{2}$.

Kelurahan Wonolopo memiliki potensi lokal yang cukup beragam, seperti kampung jamu gendong, kebun durian, Joglo Pawening Jati, river tubing, outbound, karawitan, dan festival panen raya yang diadakan tiap tahun saat musim panen. Namun demikian, jika dilihat dari kondisi di lapangan masih banyak masyarakat yang bahkan tidak mengetahui bahwa Kelurahan Wonolopo merupakan desa wisata yang telah ditetapkan menjadi wisata Kota Semarang. Jika dilihat darilokasinya, Desa Wisata Wonolopo juga belum banyak diketahui umum karena tidak adanya identitas atau penanda lokasi wisata yang menonjol. Aktivitas wisata juga sangat tertutup dikarenakan hanya masyarakat tertentu yang ikut serta dalam kegiatan wisatanya

Kelurahan Wonolopo mempunyai potensi sumberdaya alam yang didukung kondisi lahan dan iklim yang sesuai bagi pengembangan pertanian. Berbagai komoditi yang potensial di Kelurahan Wonolopo diantaranya buah durian. Tak hanya durian, kelurahan ini juga menghasilkan buah lainnya, seperti salak, jambu biji dan pepaya. Selain itu, Wonolopo menawarkan suasana pedesaan sangat kental dengan aktivitas pertanian. Kampung Jamu juga menjadi julukan bagi kelurahan ini karena sebagian penduduknya memproduksi jamu gendong secara tradisional. Bahan baku untuk membuat jamu juga memanfaatkan sumber daya alam yang ada di kelurahan Wonolopo. Penduduk Wonolopo pun juga memperbanyak tanaman toga disetiap rumah.

Perpaduan antara keindahan alam, kehidupan masyarakat pedesaan dan potensi pertanian, bilamana ditata secara baik dan ditangani secara serius dapat mengembangkan daya tarik wisata bagi kelurahan Wonolopo. Potensi unggulan yang dimiliki oleh kelurahan Wonolopo terutama di bidang pertanian, perkebunan dan pariwisata. Hal ini tidak terlepas dari posisi geografis kelurahan Wonolopo yang mempunyai letak strategis serta anugerah potensi dan kekayaan alam yang tidak dimiliki oleh kelurahan lain sehingga dapat digunakan sebagai modal yang harus dikelola dengan seoptimal mungkin. Kondisi seperti ini diharapkan dapat meningkatkan pendapatan petani sekaligus melestarikan sumber daya lahan yang tersedia. Maka dari itu kelurahan Wonolopo mempunyai potensi untuk menjadi desa agrowisata. Upaya pengembangan desa agrowisata pedesaan yang memanfaatkan potensi pertanian, perkebunan dan melibatkan masyarakat pedesaan, dapat berfungsi sebagai pemberdayaan masyarakat. Dalam pengembangan desa agrowisata, masyarakat lokal merupakan salah satu komponen yang sangat penting peranannya.

Potensi sumber daya alam yang ada di kelurahan Wonolopo masih banyak yang belum dikembangkan secara maksimal padahal kelurahan Wonolopo mempunyai potensi untuk menjadi desa agrowisata seperti yang telah diuraikan di analisis situasi diatas. Meskipun kelurahan Wonolopo berpotensi untuk menjadi desa agrowisata akan tetapi fakta empirik di lapangan menunjukkan bahwa 
agrowisata di kelurahan Wonolopo masih belum berkembang. Permasalahan mitra inilah yang merupakan prioritas permasalahan yang sudah ditentukan bersama antara tim pengabdi bersama mitra. Permasalahan itu adalah:

a. Kurang adanya pemahaman dan kesadaran warga akan potensi sumber alam dan pengembangan budaya yang ada di wilayah Wonolopo.

b. Belum terbentuknya maindset masyarakat Desa Wonolopo sebagai pelaku utama usaha agrowisata.

c. Belum terbentuknya jiwa entrepreneur atau jiwa wirausaha pada masyarakat Wonolopo.

d. Kurangnya keterampilan masyarakat dalam berkomunikasi dengan menggunakan bahasa asing.

e. Kurangnya pelatihan-pelatihan, pembinaan, pendampingan dan pemberian ketrampilan kepada penduduk Wonolopo (dalam bentuk pemberdayaan masyarakat lokal) untuk mengelola potensi alam dan budaya yang dimiliki.

f. Belum cukup tersedianya tenaga-tenaga yang cakap, terampil, dan memiliki skill yang tinggi tentang pengembangan desa agrowisata.

g. Belum maksimalnya beberapa aspek penting dalam pengembangan desa agrowisata, seperti minimya daya tarik yang menampilkan budaya masyarakat lokal, kurangnya jenis aktifitas yang dikembangkan masyarakat lokal, dan tidak adanya integrasi dengan kawasan-kawasan wisata di sekitarnya.

Untuk mengatasi semua permasalahan diatas maka perlu kerjasama yang baik antara tim pengabdi dan mitra. Pelaksanaan program ini juga dimaksudkan untuk mensinergikan kegiatan Pemerintah Kota Semarang dengan kegiatan pengabdian melalui kepakaran dan keahlian dari para pelaksana pengabdi sehingga dapat membantu masyarakat dalam mengoptimalkan potensi yang dimiliki. Selain itu program pengabdian ini juga dimaksudkan untuk mendorong pemerintah daerah agar dapat meningkatkan kegiatan usaha masyarakat dalam rangka peningkatan perekonomian masyarakat dan meningkatkan pendapatan asli daerah.

Tujuan dari kegiatan pengabdian ini adalah (1) Meningkatkan kesadaran masyarakat setempat terhadap kearifan lokal Kelurahan Wonolopo, (2) Terwujudnya pemberdayaan ekonomi masyarakat di Kelurahan Wonolopo, (3) Perubahan mindset masyarakat Kelurahan Wonolopo dalam mengembangkan desa agrowisata, (4) Produktifitas dan popularitas desa agrowisata Kelurahan Wonolopo di tingkat regional dan nasional, (5) Membuka tambahan lapangan kerja baru dan lahan ekonomi baru, (6) Meningkatkan partisipasi masyarakat Kelurahan Wonolopo.

Solusi yang ditawarkan dalam kegiatan pengabdian ini adalah (1) Workshop perubahan mindset dan menumbuhkan jiwa entrepreneur, (2) Pelatihan dan pendampingan tentang kepariwisataan berbasis MICE dan pengelolaannya, (3) Pembinaan dan pelatihan bahasa daerah dan bahasa asing untuk pemandu wisata (local tour guide), (4) Pelatihan pengolahan produk pertanian, pendampingan, dan pemasarannya, (5) Membuat website, akun facebook, akun instagram, membuat leafet atau brosur paket wisata untuk promosi program desa agrowisata.

Solusi yang ditawarkan oleh Universitas 17 Agustus 1945 Semarang berupa pelatihanpelatihan, pembinaan, pendampingan dan pemberian ketrampilan kepada warga Wonolopo (dalam bentuk pemberdayaan masyarakat lokal) yang diharapkan dapat meningkatkan SDM Kelurahan Wonolopo untuk mengelola potensi alam dan budaya yang dimiliki, meningkatkan kualitas hidup dengan menciptakan kondisi yang lebih baik untuk pertumbuhan ekonomi, penciptaan lapangan kerja sehingga hasilnya benar-benar dapat meningkatkan kesejahteraan masyarakat di sekitarnya. Keterlibatan mitra dalam hal ini warga Wonolopo bukan hanya pada aspek pelaksanaan, tetapi mulai dari komunikasi masalah, perencanaan program, serta pelaksanaan, sehingga ketercapaian target luaran dan kesinambungan program lebih terjamin.

Keberhasilan pemberdayaan masyarakat dalam pengembangan desa agrowisata di Kelurahan Wonolopo Kecamatan Mijen Kota Semarang ini menjadi salah satu kunci dalam pengembangan desa agrowisata di Kelurahan Wonolopo. Sejalan dengan itu perlu adanya pola pembinaan agrowisata agar para pelaku pariwisata dan pelaku pertanian secara sinergis dapat merencanakan, menyusun, memprogramkan agrowisata yang bermanfaat bagi masyarakat, pengusaha dan pemerintah. 


\section{Metode Pelaksanaan}

Dalam pelaksanaan program pengabdian ini akan dilakukan dengan berbagai pendekatan atau metode untuk mencapai target dan tujuan yang diharapkan. Untuk mampu mengembangkan kawasan desa agrowisata, tentu dibutuhkan suatu konsep pengembangan yang sesuai. Salah satu konsep pengembangan tersebut adalah community based tourism. Metode yang digunakan untuk mengatasi permasalahan adalah dengan melakukan pendekatan strategis program yang dilakukan dalam beberapa tahap, yaitu Tahap Persiapan, Tahap Pembinaan dan Pelatihan, Tahap Pendampingan dan evaluasi dalam pembentukan usaha bersama.

\subsection{Tahap Persiapan}

Pada tahap persiapan yang dilakukan adalah identifikasi masalah yang terdapat pada masyarakat mitra untuk mengetahui kondisi objektif kehidupan masyarakat mitra, mendata potensi yang ada, mencatat permasalahan yang ada dalam memberdayakan masyarakat melalui pengembangan desa agrowisata di Kelurahan Wonolopo Kecamatan Mijen Kota Semarang. Selain itu pada tahap ini juga dilakukan sosialisasi program kepada mitra tentang Pemberdayaan Masyarakat melalui pengembangan desa argowisata mempunyai nilai ekonomis untuk meningkatkan pendapatan masyarakat mitra.

\subsection{Tahap Pembinaan dan Pelatihan}

Pada tahapan ini diharapkan adanya partisipasi dari/setiap anggota masyarakat. Implementasi kegiatan ini berupa pelatihan pelatihan dan pemberian ketrampilan kepada warga Wonolopo (dalam bentuk pemberdayaan masyarakat lokal) yang tercantum pada bagian solusi yang ditawarkan.

\subsection{Tahap Pendampingan dan Evaluasi}

Pada tahapan pendampingan dilakukan monitoring guna mengetahui apakah pelaksanaan program sesuai dengan rencana program yang telah dibuat. Tahap ini penting untuk menjaga keberlanjutan dari pengembangan desa agrowisata. Masukan-masukan hasil dari monitoring dan evaluasi dari masyarakat maupun pihak pihak terkait dapat digunakan untuk meningkatkan kualitas dan meningkatkan manfaat dan kesejahteraan masyarakat dari adanya pemberdayaan masyarakat melalui desa agrowisata di Kelurahan Wonolopo.

Pada akhir program, tim pengusul akan melaksanakan evaluasi sebagai umpan balik dari pelaksanaan program. Evaluasi dilakukan untuk mengetahui apakah pelatihan yang sudah dilakukan dapat memberikan kontribusi pada mitra untuk menyelesaikan masalah yang dihadapi mitra pada program PKM ini. Tidak hanya itu, pelatihan juga perlu dievaluasi untuk memutuskan apakah program pelatihan tersebut perlu dilanjutkan atau tidak, yang terakhir adalah evaluasi program dilakukan untuk mendapatkan informasi mengenai bagaimana meningkatkan dan mengembangkan program pelatihan yang akan datang.

\section{Hasil dan Pembahasan}

Kegiatan yang pertama kali dilakukan adalah koordinasi dengan tim pengabdi terkait dengan teknis pelaksanaan program. Koordinasi dengan tim dilaksanakan pada tanggal 4 Mei 2020 di FBB UNTAG Semarang. Dari hasil koordinasi dengan tim kemudian dilanjutkan koordinasi dengan mitra terkait dengan kegiatan PKM yang akan diagendakan. Koordinasi dengan mitra dilaksanakan pada tanggal 9 Mei 2018 di rumah bu Sumitri selaku salah satu anggota Pokdarwis Manggar di kelurahan Wonolopo. Dalam koordinasi ini dibahas macam macam kegiatan yang akan dilaksanakan selama kegiatan PKM. Diharapkan jadwal yang sudah didiskusikan dengan mitra dapat berjalan dengan baik. Namun karena kondisi pada saat ini dengan adanya pandemi Covid 19, maka pelaksanaan kegiatan pengabdian disesuaikan dengan keadaan di lapangan. Kegiatan dapat dilakukan dengan dua cara yaitu dengan daring atau dengan offline. Jika pelaksaanan dilakukan secara offline atau tatap muka maka teknis pelaksanaan tetap memperhatikan protokol kesehatan yang berlaku serta mendapat ijin dari mitra. Kegiatan yang sudah dilaksanakan dalam program pengabdian ini adalah sebagai berikut. 


\subsection{Pelatihan dan Pendampingan Pengolahan Produk Pertanian Berbahan Baku Lokal}

Potensi unggulan yang dimiliki oleh kelurahan Wonolopo terutama di bidang pertanian. Pada bidang pertanian, warga kelurahan wonolopo masih memanfaatkan lahan yang dimiliki dengan menanam ketela rambat. Selama ini produksi ketela rambat yang dihasilkan dari pertanian warga, sebagian besar hanya dimanfaatkan warga dengan menjualnya secara langsung kepada penjual sehingga hanya berdaya jual rendah dan sebagian ada yang dijual dengan diolah terlebih dahulu menjadi gorengan. Melihat hal tersebut, masih minimnya pengolahan ketela rambat yang variatif dan higienis.

Pelatihan pengolahan produk pertanian berbahan baku lokal dilaksanakan pada hari Minggu, 14 Juni 2020. Kegiatan ini dilaksanakan di Balai Air RT 05 RW 04 Kelurahan Wonolopo Kecamatan Mijen Kota Semarang. Kegiatan ini diikuti oleh ibu ibu anggota dari Pokdarwis Manggar sebanyak 12 orang. Pemateri dalam kegiatan ini adalah Ibu Maemunah, beliau adalah seorang praktisi dalam bidang makanan ringan dan jajanan pasar. Pada saat pelatihan ini, ibu ibu anggota Pokdarwis Manggar diajarkan bagaimana membuat bahan baku ketela rambat menjadi olahan yang lebih bervariatif dan memiliki nilai jual yang tinggi. Olahan yang dibuat adalah cake ketela rambat, sus fla ketela ungu dan onde-onde ubi ungu. Dalam pelatihan ini, Ibu Maemunah juga menyampaikan bahwa dalam pembuatan olahan bahan baku ketela rambat ini perlu diperhatikan penyajian dan higienitasnya sehingga hasilnya adalah makanan yang sehat, aman, berpenampilan menarik dan mempunyai nilai jual yang tinggi.

Pelatihan ini sangat bermanfaat terutama bagi ibu ibu anggota Pokdarwis Manggar untuk meningkatkan perekonomian keluarga mereka. Di tempat wisata yang ada di Kelurahan Wonolopo masih terbatas jajanan khas maupun oleh-oleh kuliner yang ada sehingga dengan adanya pelatihan ini ibu ibu menjadi terangsang untuk mencipta dan memasarkan aneka kuliner olah ketela rambat tersebut sebagai salah satu ikon kuliner desa agrowisata Kelurahan Wonolopo. Selain itu pelatihan ini bertujuan untuk meningkatkan kesejahteraan masyarakat kelurahan Wonolopo.

Peserta terlihat sangat antusias dengan adanya pelatihan tersebut. Diharapkan setelah kegiatan ini, para peserta dapat menginformasikan dan menyebarluaskan ilmu yang telah didapatkan selama pelatihan kepada masyarakat lainnya dan selanjutnya dapat lebih memanfaatkan bahan pangan lokal dalam upaya pemenuhan kebutuhan konsumsi pangan keluarga.

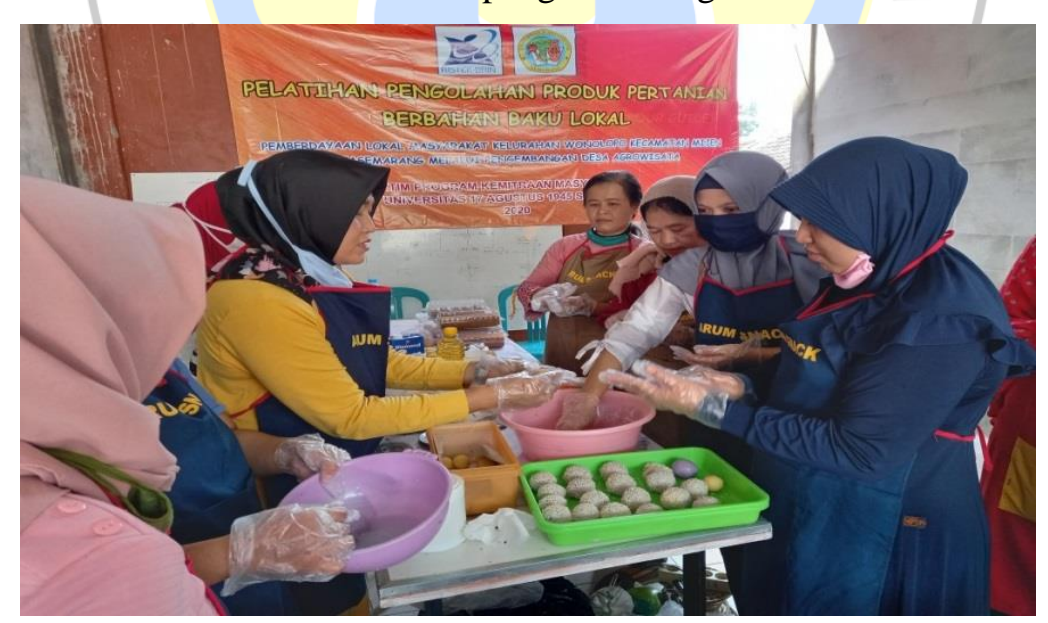

Gambar 1. Pelatihan Pengolahan Produk Pertanian Berbahan Baku Lokal

\subsection{Pembinaan dan Pelatihan Bahasa Daerah dan Bahasa Asing Untuk Pemandu Wisata}

Bahasa asing, khususnya bahasa Inggris merupakan sarana komunikasi yang sangat penting untuk memperkenalkan daya tarik wisata secara internasional. Pengelolaan pariwisata tanpa didukung dengan keterampilan dan kecakapan berbahasa asing akan menghambat kelancaran dan komunikasi serta pelayanan terhadap wisatawan asing. Para guide adalah yang berinteraksi langsung dengan wisatawan dan sumber informasi utama wisatawan ketika mengunjungi sebuah objek wisata. Oleh karena itu, mereka wajib memiliki kemampuan berbahasa yang memadai 
Pelatihan dan praktik bahasa inggris ini dilakukan pada hari Sabtu, 27 Juni 2020. Pelatihan ini diikuti oleh anggota Pokdarwis Manggar Kelurahan Wonolopo. Tujuan diadakannya pelatihan ini adalah membantu para anggota Pokdarwis Manggar dalam memotivasi diri dan mengoptimalkan potensi yang mereka miliki dalam berkomunikasi menggunakan bahasa Inggris sehingga mereka dapat memberikan sumbangan yang berarti bagi orang lain, dan terlebih lagi bagi pengembangan karir mereka sendiri.

Pemateri pada pelatihan ini adalah Bapak Sony Junaedi. Beliau adalah salah satu dosen bahasa inggris di UNTAG sekaligus sebagai ketua pengabdi dalam kegiatan ini. Pada pelatihan bahasa Inggris materi yang diberikan adalah English Vocabulary in Tourism Guides, Local Guides conversations, Some expressions in tourism, General information about tourism dan Excellent services in tourism. Dalam pelatihan ini, peserta juga melakukan praktek cara berkomunikasi dengan wisatawan menggunakan bahasa inggris. Bapak Sony Junaedi juga mengatakan dalam mengasah kemampuan berbahasa inggris ini perlu pembiasan berulang ulang agar kosa katanya semakin banyak dan lancar dalam berkomunikasi dengan wisatawan asing.

Kegiatan Pelatihan dan praktik bahasa inggris bagi anggota Pokdarwis Manggar ini akan sangat bermanfaat langsung bagi para anggota tersebut untuk meningkatkan kemampuan berkomunikasi mereka dengan para wisatawan. Pelatihan ini penting dilakukan mengingat kendala bahasa sampai saat ini masih merupakan masalah dalam memberikan informasi kepada wisatawan. Kendala bahasa yang akan difokuskan untuk dilatih yaitu dalam skil berbicara yang meliputi penggunaan languageexpression dan kosa kata, tata bahasa, pengucapan dan kelancaran. Dengan diadakannya pelatihan ini, maka kemampuan berbahasa Inggris para anggota pokdarwis bisa meningkat sehingga memperlancar komunikasi dengan wisatawan. Pelatihan ini juga akan membantu meningkatkan kemampuan berkomunikasi dengan para tamu. Hal ini tentu saja akan mempengaruhi kesan dan minat para wisatawan terhadap objek wisata yang ada di Kelurahan Wonolopo.

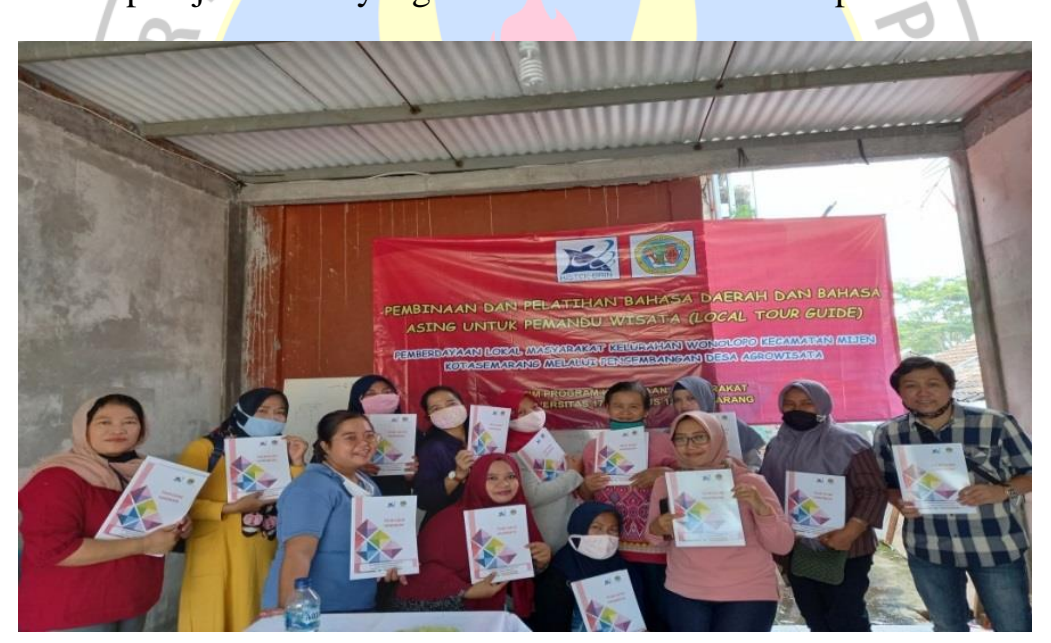

Gambar 2. Pelatihan dan Praktik Bahasa Inggris

Dalam upaya mendukung pengembangan desa agrowisata di kelurahan wonolopo banyak hal bisa dilakukan untuk bisa menjaring wisatawan baik asing maupun domestik. Wisatawan domestikpun juga akan merasa senang jika disuguhi dengan etika kesantunan dalam berbahasa Jawa (unggah-ungguh). Pelatihan dan praktik bahasa jawa ini dilaksanakan pada hari Minggu, 19 Juli 2020. Kegiatan ini dilaksanakan di SD Negeri Wonolopo 01 Kelurahan Wonolopo Kecamatan Mijen Kota Semarang. Kegiatan ini diikuti oleh anggota dari Pokdarwis Manggar sebanyak 12 orang. Pemateri dalam kegiatan ini adalah Bapak Bambang Sulanjari, beliau adalah dosen Pendidikan Bahasa dan Sastra Daerah di Universitas PGRI Semarang. Materi yang disampaikan dalam kegiatan pelatihan ini adalah Pranata cara bahasa Jawa dan Budaya Jawa.

Pemateri dalam kegiatan ini juga menyampaikan bagaimana menggunakan unggah-ungguh bahasa Jawa ragam krama ( ragam tingkat tutur bahasa Jawa yang tertinggi, halus dan sopan). Penggunaan bahasa jawa ragam krama ini dimaksudkan untuk memberi rasa hormat kepada orang 
lain. Kepentingan meninggikan ini dipengaruhi oleh status sosial atau usia yang lebih tinggi. Bahasa Jawa ragam krama dipakai jika pihak 1 bermaksud meninggikan pihak 2 atau 3 atau keduanya.Akan tetapi, bahasa Jawa krama tidak tepat digunakan untuk meninggikan pihak 1 (atau dirinya sendiri ). Tentu apabila unggah-ungguh atau tingkat tutur bahasa Jawa ini juga dapat digunakan dengan baik, wisatawan yang penutur Jawa akan senang dan merasa dihormati, sehingga berimbas pada keakraban yang terjalin sangat baik.

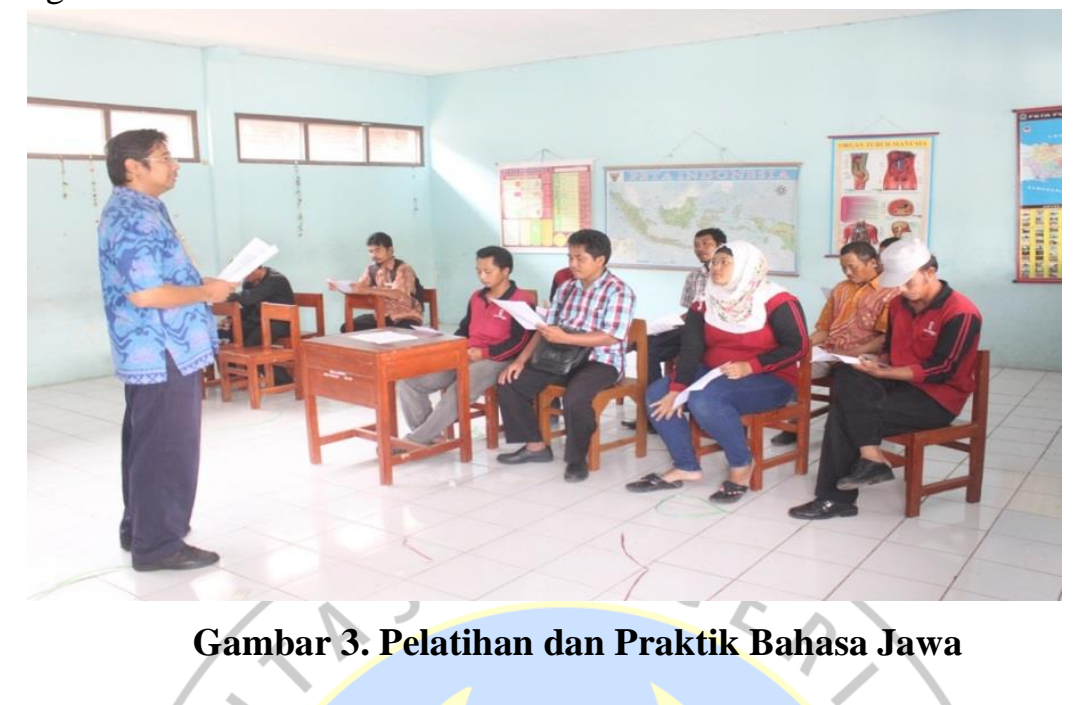

\subsection{Webinar Perubahan Mindset Dan Menumbuhkan Jiwa Entrepreneur}

Webinar menumbuhkan jiwa entrepreneur yang kreatif, mandiri dan inovatif di masa pandemi dilaksanakan pada hari Sabtu, 8 Agustus 2020 secara online yang diadakan oleh Imperium 17 Program Studi Kesehatan Masyarakat Fakultas Kedokteran Universitas Lambung Mangkurat. Pokdarwis Manggar mengikuti kegiatan webinar ini dengan menyaksikan materi yang disampaikan melalui Laptop ataupun HP masing-masing peserta. Peserta yang mengikuti kegiatan ini mendapatkan sertifikat. Pemateri dalam kegiatan ini adalah Robbi Noer Miftah (Ketua Umum BPC HIPMI Kota Banjarbaru Periode 2019-2022), Zakaria Abdur Rahman, ST (Co-Founder Gepro.id), dan Wahyudi, SKM (Alumnus PSKM FK ULM dan Wirausaha Muda). Kewirausahaan merupakan kegiatan untuk meningkatkan kesejahteraan masyarakat dalam arti tingkat hidup yang lebih baik lagi. Kewirausahaan sangat besar peranannya dalam perkembangan pertumbuhan ekonomi. Dengan kewirausahaan diharapkan dapat mengurangi tingkat pengangguran di Indonesia. Kewirausahaan yang berlandaskan sikap kreatif dan inovatif mampu bertahan dengan kondisi ekonomi yang sulit. Dalam menjalankan suatu usaha, wirausahawan harus memiliki skill (kemampuan) sebagai modal utama wirausawan dalam menjalankan usahanya. Tekad (kemauan) juga harus dimiliki oleh wirausahawan, karena jika tidak ada tekad maka usaha tidak akan berjalan dengan baik.

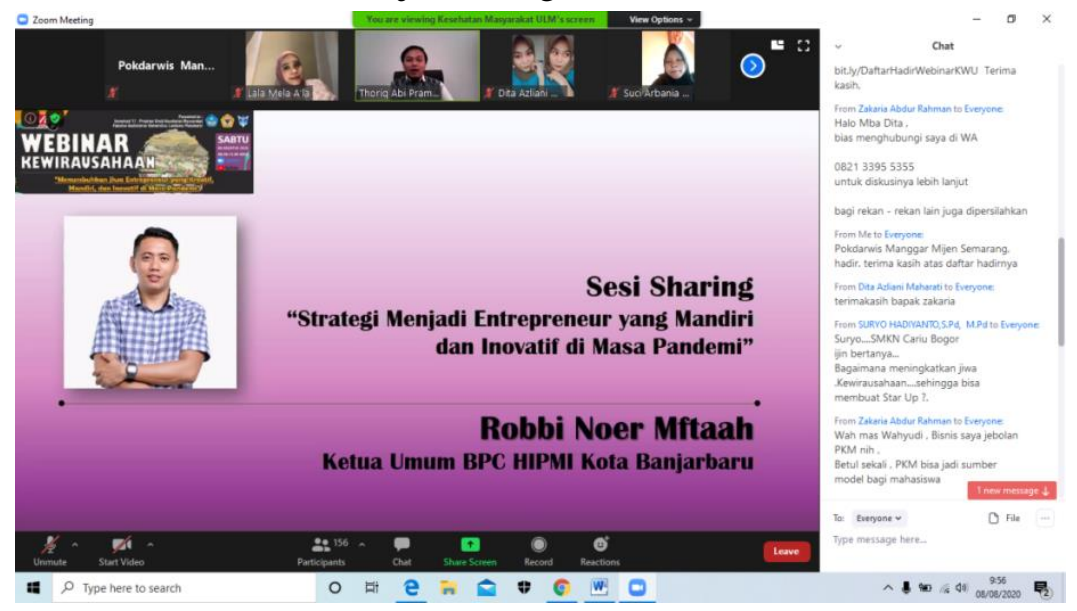

Gambar 4. Webinar Menumbuhkan Jiwa Entrepreneur Yang Kreatif 


\subsection{Pelatihan dan Pendampingan Tentang Kepariwisataan Berbasis MICE}

Dunia MICE adalah dunia yang belum terjamah dengan baik di Indonesia. Padahal dunia MICE merupakan salah satu andalan pariwisata di beberapa negara maju. Dunia MICE merupakan salah satu dunia bisnis yang menjanjikan. Namun baru sedikit sekali pihak Indonesia yang mau bermain di dunia MICE. Mungkin salah satu penyebabnya adalah kurangnya pengetahuan tentang MICE di Indonesia. Namun di Indonesia sudah mulai ada lembaga pendidikan yang memberikan pendidikan tentang MICE. Banyak negara yang sudah menjadikan dunia MICE sebagai salah satu potensi wisatanya.

Pelatihan tentang kepariwisataan berbasis Mice dilaksanakan pada hari Minggu, 14 September 2020. Kegiatan ini dilaksanakan di Balai Air RT 05 RW 04 Kelurahan Wonolopo Kecamatan Mijen Kota Semarang. Kegiatan ini diikuti oleh anggota dari Pokdarwis Manggar sebanyak 12 orang. Pemateri dalam kegiatan ini adalah Ibu Vera Damayanti, beliau adalah dosen dari Fakultas Bahasa dan Budaya Universitas 17 Agustus 1945 Semarang sekaligus sebagai Direktur Lembaga Serifivikasi Pariwisata Guna Dharma Semarang.

Dalam pelatihan ini, Ibu Vera menyampaikan bahwa MICE adalah merupakan suatu rangkaian kegiatan, dimana para pengusaha atau professional berkumpul pada suatu tempat yang terkondisikan oleh suatu permasalahan, pembahasan, atau kepentingan yang sama. MICE telah menjadi suatu saran sekaligus produk yang dapat dikategorikan dalam paket-paket wisata siap dijual kepada asosiasi. Industri MICE menurut Indrajaya (2015:83) memiliki potensi pertumbuhan positif seiring membaiknya perekonomian dan naiknya pendapatan masyarakat, keberhasilan pembangunan industri MICE memiliki multiplier effect yang sangat besar karena melibatkan begitu banyak pelaku bisnis diantaranya pihak yang potensial mendapatkan keuntungan besar bisnis MICE yaitu percetakan, hotel, perusahaan souvenir, biro perjalanan wisata, transportasi, professional conference organizer (PCO), usaha kecil dan menengah (UKM), dan event organizer. Banyak sektor terkait dengan industri MICE, yaitu (1) industri perhotelan, (2) restoran, (3) kerajinan, (4) biro perjalanan udara dan darat, (5) kuliner (makanan), (6) penerjemah, dan lain-lain.

Peserta terlihat sangat antusias dengan adanya pelatihan tersebut. Diharapkan setelah kegiatan ini, para peserta dapat menginformasikan dan menyebarluaskan ilmu yang telah didapatkan selama pelatihan kepada masyarakat lainnya dan selanjutnya dapat lebih memanfaatkan kerja sama atau berkolaborasi dengan berbagai stakeholder agar tercipta MICE di desa Wonolopo sebagai desa agrowisata.

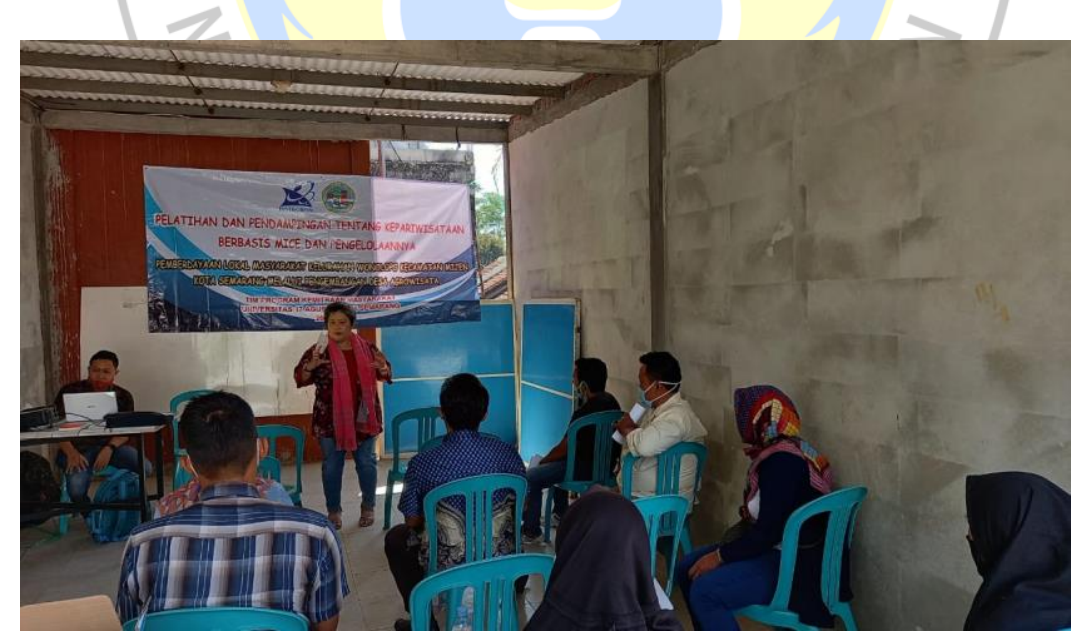

\section{Gambar 5. Pelatihan dan Pendampingan Tentang Kepariwisataan Berbasis MICE}

\subsection{Membuat Website, Akun Facebook, Akun Instagram}

Penggunaan teknologi sebagai media pencarian informasi kini dimudahkan dengan hadirnya sosial media yang memungkinkan komunikasi atau dialog interaktif. Perkembangan teknologi juga memungkinkan tersampaikannya konten-konten menarik berupa teks, gambar, audio, dan video yang dapat memberikan informasi secara jelas tentang produk maupun jasa yang ditawarkan. Tidak terkecuali sosial media juga banyak digunakan oleh industri pariwisata. Potensi sosial media sebagai 
sarana promosi interaktif bagi pariwisata Indonesia menjadi topik penelitian menarik dan sangat dibutuhkan dalam upaya meningkatkan industri pariwisata. Konten yang diposting di sosial media memberikan kontribusi yang cukup signifikan, tidak saja terhadap bisnis jasa pariwisata, namun juga memberikan keuntungan kepada wisatawan yang akan melakukan wisata, diantaranya berupa informasi tentang kualitas layanan, pengalaman, sampai variasi harga yang menarik. Untuk itu, agar desa agrowisata di Desa Wonolopo bisa lebih terkenal di masyarakat luas, tim pengabdi membuatkan akun media sosial untuk Desa Agrowisata Wonolopo.

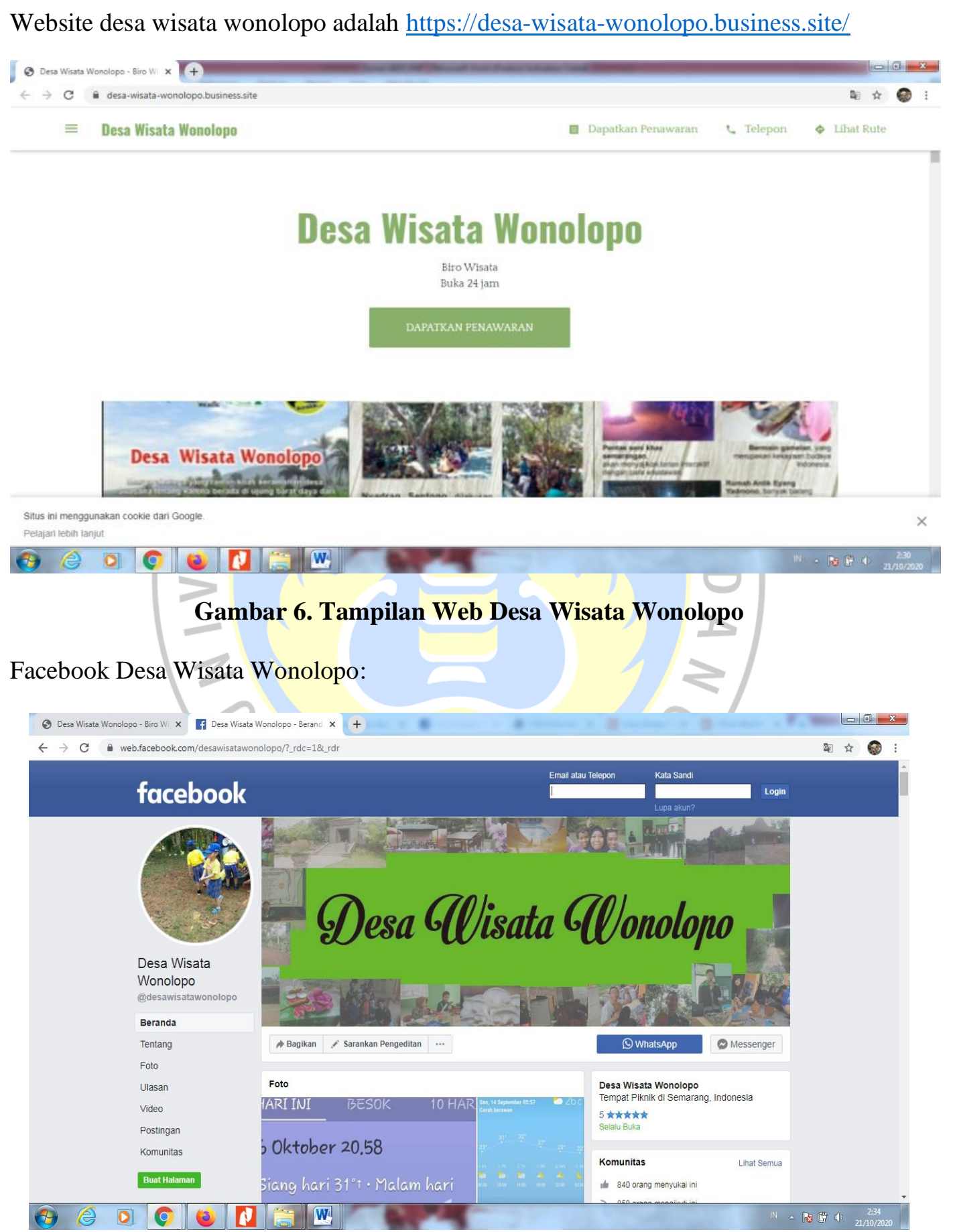

Gambar 7. Tampilan Facebook Desa Wisata Wonolopo 
Instagram Desa Wisata Wonolopo

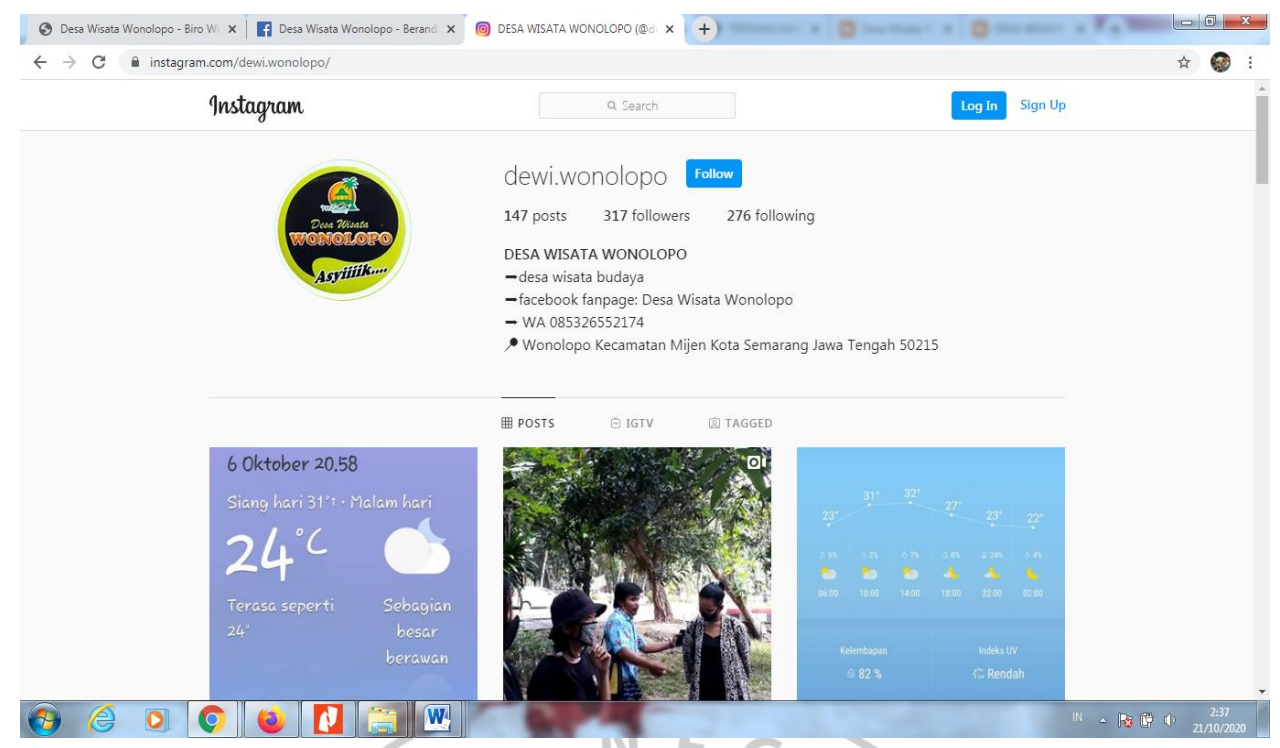

\section{Gambar 8. Tampilan Instagram Desa Wisata Wonolopo}

\section{Kesimpulan}

Pokdarwis Manggar Kelurahan Wonolopo Kecamatan Mijen Kota Semarang sangat respond dan mendukung seluruh kegiatan pengabdian ini terlihat dari antusiasme mitra dalam mengikuti pelatihan dan workshop. Kegiatan yang sudah dilaksanakan dalam pengabdian ini adalah (1) Pelatihan pengolahan produk pertanian berbahan baku lokal, (2) Pelatihan dan praktik bahasa inggris, (3) Pelatihan dan praktik bahasa jawa, (4) Webinar menumbuhkan jiwa entrepreneur yang kreatif, (5) Pelatihan dan Pendampingan Tentang Kepariwisataan Berbasis MICE, dan (6) Membuat website, facebook dan instagram untuk menunjang promosi dan pemasaran Desa Agrowisata Wonolopo. Pokdarwis Manggar Kelurahan Wonolopo Kecamatan Mijen Kota Semarang mengharapkan ada pelatihan yang beragam guna mendukung pelatihan yang sudah dilaksanakan.

\section{Daftar Pustaka}

Atras, A \& Rahmawati, R. (2015). Faktor-Faktor yang Berpengaruh terhadap Pengembangan Kawasan Agrowisata melalui Pendekatan Community Based Tourism di Kecamatan Bumiaji Kota Batu. Jurnal Teknik ITS, 4(2), 92-97.

BPS Kota Semarang. (2015). "Kecamatan Mijen dalam angka 2015". Semarang: Badan Pusat Statistik Kota Semarang.

Hadiwijoyo, S. S. (2012). Perencanaan pariwisata perdesaan berbasis masyarakat: Sebuah pendekatan konsep. Yogyakarta: Graha Ilmu.

Pemerintah Kota Semarang. (2012). Surat Keputusan Walikota Semarang Nomor: 556/407 Tanggal 21 Desember 2012 Tentang Penetapan Kelurahan Wonolopo Kecamatan Mijen sebagai Desa Wisata Kota Semarang berbasis Daya Tarik Alam dan Daya Tarik Budaya. Semarang: Kantor Pemerintah Kota Semarang

Tati, Budiarti, dkk. (2013). Pengembangan Agrowisata Berbasis Masyarakat pada Usahatani Terpadu guna Meningkatkan Kesejahteraan Petani dan Keberlanjutan Sistem Pertanian. Jurnal Ilmu Pertanian Indonesia (JIPI), 18(3), 200-207. 